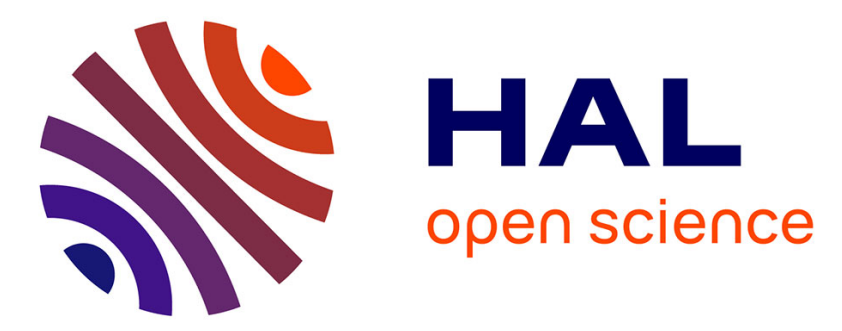

\title{
Influence of Heating Rate and Carbon Concentration on the Mechanical Properties of Carbon Steels
}

\author{
L. Cau, M. Abdelaziz, W. Kaluba, G. Mesmacque
}

\section{To cite this version:}

L. Cau, M. Abdelaziz, W. Kaluba, G. Mesmacque. Influence of Heating Rate and Carbon Concentration on the Mechanical Properties of Carbon Steels. Journal de Physique IV Proceedings, 1996, 06 (C1), pp.C1-109-C1-117. 10.1051/jp4:1996111 . jpa-00254143

\section{HAL Id: jpa-00254143 https://hal.science/jpa-00254143}

Submitted on 1 Jan 1996

HAL is a multi-disciplinary open access archive for the deposit and dissemination of scientific research documents, whether they are published or not. The documents may come from teaching and research institutions in France or abroad, or from public or private research centers.
L'archive ouverte pluridisciplinaire HAL, est destinée au dépôt et à la diffusion de documents scientifiques de niveau recherche, publiés ou non, émanant des établissements d'enseignement et de recherche français ou étrangers, des laboratoires publics ou privés. 


\title{
Influence of Heating Rate and Carbon Concentration on the Mechanical Properties of Carbon Steels
}

\author{
L. Cau, M.N. Abdelaziz, W. Kaluba* and G. Mesmacque
}

Laboratoire de Mécanique de Lille,URA 1441 du CNRS, IUT Lille I, Dept. Génie Mécanique et

Productique, 2 rue de la Recherche, BP. 179, 59653 Villeneuve d'Ascq cedex, France

* IUT du Littoral, Dept. Maintenance Industrielle, rue Descartes, 62968 Longuenesse, France

\begin{abstract}
In this work, the influence of temperature and heating rate on mechanical properties of three carbon steels (containing respectively $0.1 \%, 0.38 \%$ and $1 \%$ of carbon) has been investigated. Using a specifically designed apparatus equipped with a heating device, tensile and relaxation tests have been performed in air under three conditions of temperature $\left(600^{\circ} \mathrm{C}, 800^{\circ} \mathrm{C}\right.$ and $\left.1100^{\circ} \mathrm{C}\right)$ and for two extreme values of heating rate $\left(10^{\circ} \mathrm{C} / \mathrm{s}\right.$ and $270^{\circ} \mathrm{C} / \mathrm{s}$ respectively). A significant dependence of mechanical properties ( such as the yield stress and the maximal stress) upon the rate of heating has been pointed out. For instance, at $600{ }^{\circ} \mathrm{C}$, for each material, an essential decrease of the yield stress as well as the flow stress was observed for the heating rate of $270{ }^{\circ} \mathrm{C} / \mathrm{s}$. Moreover, for a given temperature value, our results show that this parameter also affects the strain hardening factor as well as the strain rate sensitivity exponent.
\end{abstract}

\section{INTRODUCTION}

The mechanical properties of steels are generally affected by physical parameters such as strain rate and temperature [1-3] as well as by the chemical composition and the microstructure.

Moreover, thermal history of the material including both temperature and heating rate may be an additional factor likely to modify its mechanical behaviour. For instance, it is well known that austenite just after transformation exhibits a relatively high level of flow stress [4].

According to many authors [5,6], two different modes of transformation are possible to appear when heating $\mathrm{Fe}-\mathrm{C}$ alloy up to austenitization temperature:

- the first one is thermally activated ( with diffusion process).

- the second one is achieved without thermal activation (diffusionless mechanism).

As these mechanisms are controlled by the heating rate [7-10], a significant influence of this parameter on the mechanical behaviour of the material should be expected.

This behaviour can be described by the evolution of the true stress as a function of both the true strain and the strain rate, using constitutive laws which proceed from thermodynamics analysis

The most useful one is the relationship developed by Norton-Hoff [11] because it needs only three parameters to be identified. In this relationship, true plastic stress $\sigma_{p}$ is expressed as a multiplicative form of both the plastic strain $\varepsilon_{p}$ and the strain rate $\dot{\varepsilon}_{p}$ :

$$
\sigma_{\mathrm{p}}=\mathrm{K} \varepsilon_{\mathrm{p}}^{\mathbf{n}_{\mathrm{p}}} \dot{\varepsilon}_{\mathrm{p}}^{\mathrm{m}}
$$


$\mathrm{K}, \mathrm{n}$ and $\mathrm{m}$ are respectively the resistance factor, the strain hardening factor and the strain rate sensitivity exponent which can be identified through appropriate mechanical tests such as tensile and relaxation tests.

The purpose of this work is to investigate the influence of the heating rate on the mechanical behaviour and properties of three different steels. The nominal temperatures of heating were chosen so as to obtain different structural states of the material before the deformation was applied.

\section{EXPERIMENTAL PROCEDURE}

\subsection{Materials and specimens}

The specimens used in this investigation were made of $0.1 \%, 0.38 \%$ and $1 \% \mathrm{C}$ after a normalization treatment.

Their respective chemical compositions are summarized in table 1 and the dimensions of the sample are given in figure 1.

\begin{tabular}{ccccccccccc}
\hline Steel & $\mathrm{C} \%$ & $\mathrm{Mn} \%$ & $\mathrm{Si} \%$ & $\mathrm{~S} \%$ & $\mathrm{P} \%$ & $\mathrm{Ni} \%$ & $\mathrm{Cr} \%$ & $\mathrm{Mo} \%$ & $\mathrm{Cu} \%$ & $\mathrm{Al} \%$ \\
\hline $\mathrm{XC10}$ & 0.09 & 0.53 & 0.19 & 0.02 & 0.01 & $\mathrm{X}$ & 0.12 & $\mathrm{X}$ & 0.21 & 0.003 \\
$\mathrm{XC} 38$ & 0.38 & 0.65 & 0.23 & 0.03 & 0.032 & 0.02 & 0.14 & 0.01 & 0.22 & $\mathrm{X}$ \\
$\mathrm{XC100}$ & 1 & 0.16 & 0.25 & 0.012 & 0.014 & 0.1 & 0.07 & 0.01 & 0.14 & $\mathrm{X}$ \\
\hline
\end{tabular}

Table 1 : Chemical compositions

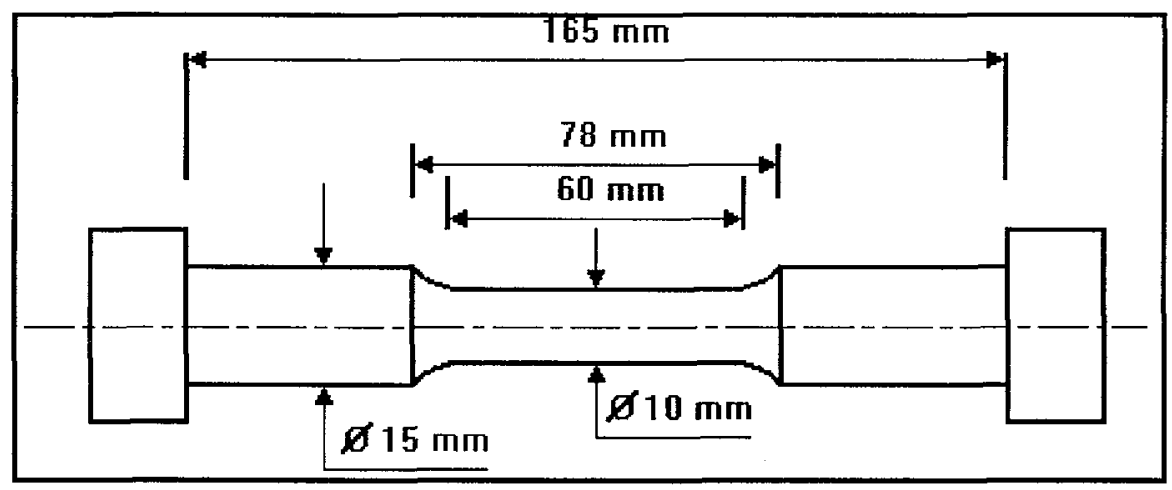

Figure 1 : Dimensions of the specimen

\subsection{Thermomechanical tests}

In order to identify the parameters in expression (1) and to determine the mechanical properties, tensile tests (elongation at constant strain rate) and relaxation tests (evolution of the stress at constant strain) were performed on a specifically designed apparatus equipped with a heating device we have developed in our laboratory.

As schematized in figure 2, the specimens were heated up to the required temperature using the Joule effect in the specimen itself as a resistance to which a high amperage alternating current is applied. 


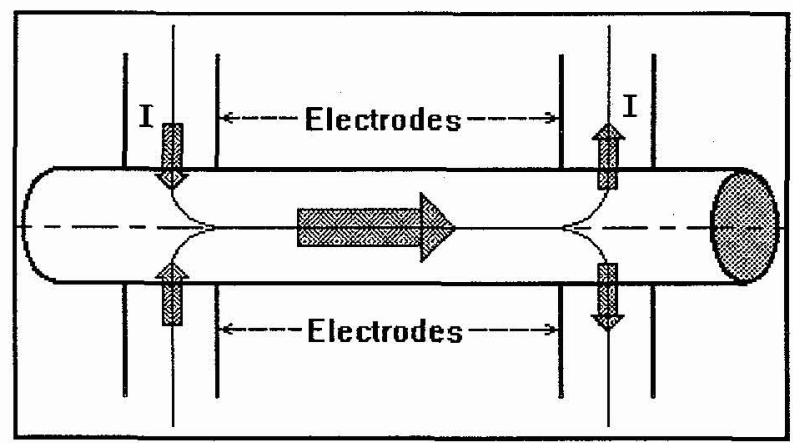

Figure 2 : Heating device

For the tensile tests, when the nominal temperature was reached, the current was switched off and the deformation of the specimen started immediately under a constant strain rate of about $0.2 \mathrm{~s}^{-1}$ up to the maximal load corresponding to necking occurrence. The deformation was achieved in a sufficiently short time (about 1 to 2 seconds) in order to minimize the effects of the temperature decrease on the measured mechanical properties.

Concerning the relaxation tests, the same heating procedure was carried out but the nominal temperature was maintained during elongation and stress relaxation period. In this case, all the specimens were strained up to a deformation value of about $6 \%$, which was then maintained constant during stress relaxation.

These procedures are schematically illustrated in figures 3-4.

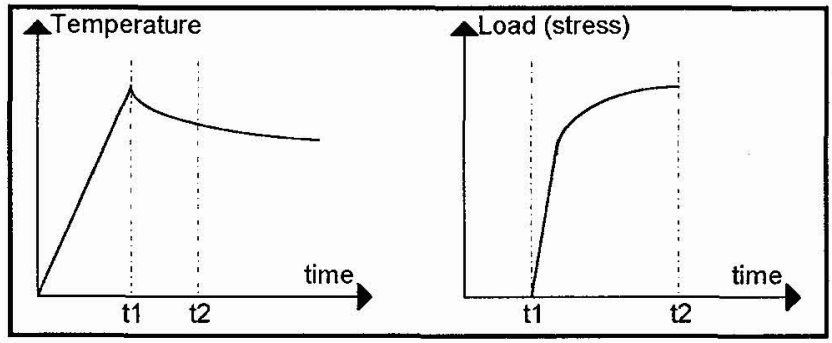

Figure $3:$ Thermomechanical cycle - tensile test.

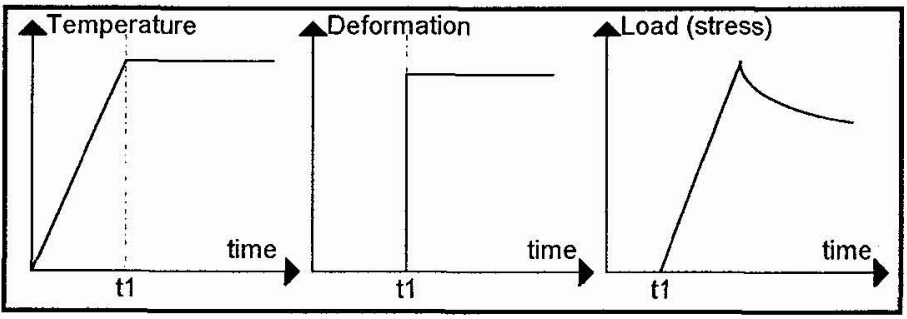

Figure 4 : Thermomechanical cycle - relaxation.

During the above mentioned experiments, the following parameters are computer controlled:

*The rate of heating, which is a function of the current intensity:

Two extreme values have been checked for this parameter: $10^{\circ} \mathrm{C} / \mathrm{s}$ and $270^{\circ} \mathrm{C} / \mathrm{s}$. The lower value was chosen in order to further the thermally activated mode of transformation while a diffusionless process may be expected for the higher value of this parameter [7]. 
*The nominal temperature of deformation, measured by means of infrared pyrometry.

-A temperature gradient along the specimen axis has been pointed out by previous measurements. Nevertheless a merely constant value of the temperature has been observed in a central part of the specimen with a reasonable dimension of about $15 \mathrm{~mm}$ in which this parameter is controlled.

-In order to take into account the phase transformation effects, the experiments were performed in three different temperature regions :

$\mathrm{T}$ nom $=600^{\circ} \mathrm{C}<\mathrm{Al}$ : no phase transformation occurrence.

$\mathrm{A} 1<\mathrm{Tnom}=800^{\circ} \mathrm{C}<\mathrm{Am}$ : two phases (ferrite and austenite or cementite and austenite) are present .

Tnom $=1100^{\circ} \mathrm{C}>\mathrm{Am}$ : the austenitization process is entirely achieved $[9,12]$.

*The strain is measured in the central part of the specimen using a high temperature extensometer with an average gauge of $11 \mathrm{~mm}$.

*The load measurements are provided by a conventional load cell.

\section{RESULTS AND DISCUSSION}

\subsection{Yield stress, maximal stress and flow stress}

The yield and maximal stresses are obtained from 2 or 3 tests and the average values are given with a margin of error of $\pm 4 \%$ at most.

$* \mathrm{~T}^{\circ}$ nom $=600^{\circ} \mathrm{C}<\mathrm{A}_{1}$

The evolution of the true plastic stress $\sigma_{p}$ as a function of the true strain $\varepsilon_{p}$ is presented in figure 5 . The conventional yield stress $\sigma_{0.2 \%}$ and maximal stress $\sigma_{\mathrm{m}}$ are given in table 2 .

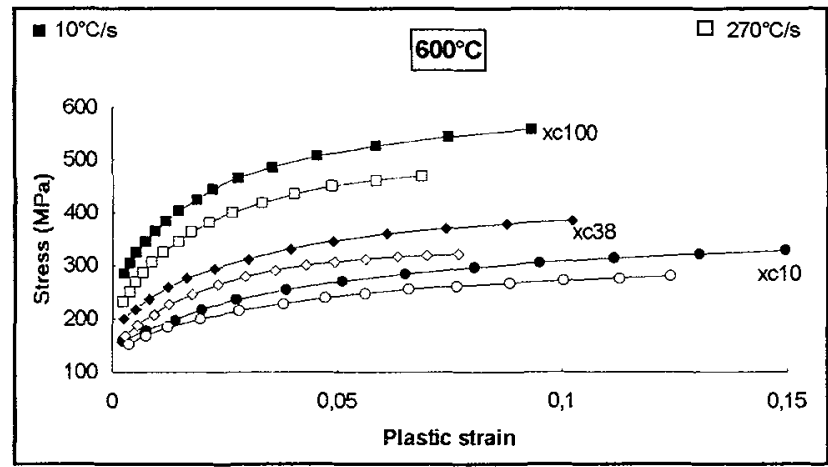

Figure 5: True plastic stress vs plastic strain $\left(600^{\circ} \mathrm{C}\right)$.

\begin{tabular}{ccccc} 
& \multicolumn{2}{c}{$\sigma_{02} \%(\mathrm{MPa})$} & \multicolumn{2}{c}{$\sigma_{\mathrm{m}}(\mathrm{MPa})$} \\
\cline { 2 - 5 } & $10^{\circ} \mathrm{C} / \mathrm{s}$ & $270^{\circ} \mathrm{C} / \mathrm{s}$ & $10^{\circ} \mathrm{C} / \mathrm{s}$ & $270^{\circ} \mathrm{C} / \mathrm{s}$ \\
\hline XC10 & 147 & 136 & 328 & 280 \\
XC38 & 200 & 178 & 385 & 321 \\
XC100 & 296 & 243 & 557 & 468 \\
\hline
\end{tabular}

Table 2 : Yield stress and maximal stress $\left(600^{\circ} \mathrm{C}\right)$. 
In this range of temperature, the grain boundaries constitute the main impediments to the dislocation motion [13]. The yield and maximal stresses as well as the flow stress increases with respect to carbon concentration.

Moreover, for each material, an essential decrease of yield and flow stresses is easy to observe for the heating rate of $270^{\circ} \mathrm{C} / \mathrm{s}$. This result is of a great practical importance.

According to Gridnev et al [14], local heat concentration sites may occur around cementite particles because of their higher electrical resistivity. Because of the thermal stresses induced by this local temperature gradient, which may be itself heating rate dependent, an increase of the dislocation density with the heating rate should be expected. This may be one possible explanation of this significant drop of both the yield and the flow stresses for this range of temperature.

* $\mathrm{A}_{1}<\mathrm{T}^{\circ}$ nom $=800^{\circ} \mathrm{C}<\mathrm{A}_{\mathrm{m}}$

The same evolution of the characteristics with respect to the carbon concentration has been observed for this temperature level as illustrated in figure 6 .

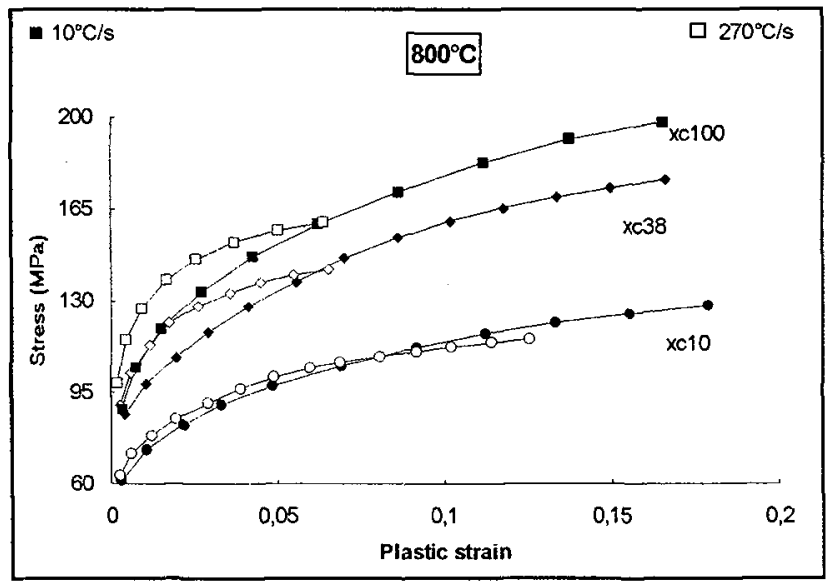

Figure 6: True plastic stress vs plastic strain $\left(800^{\circ} \mathrm{C}\right)$

But the heating rate effects are quite different since the yield (table 3) and the flow stresses (fig 6) increase with respect to this parameter. For this range of temperature, the evolution of the mechanical properties must be essentially connected to the different phases which are present, since their respective percentages are of course both temperature and heating rate dependant. The incomplete dissolution of cementite particles, when considering the higher rate of heating, seems to be one the main factor which explains this increase.

\begin{tabular}{ccccc} 
& \multicolumn{2}{c}{$\sigma_{02} \%(\mathrm{MPa})$} & \multicolumn{2}{c}{$\sigma_{\mathfrak{m}}(\mathrm{MPa})$} \\
\cline { 2 - 5 } & $10^{\circ} \mathrm{C} / \mathrm{s}$ & $270^{\circ} \mathrm{C} / \mathrm{s}$ & $10^{\circ} \mathrm{C} / \mathrm{s}$ & $270^{\circ} \mathrm{C} / \mathrm{s}$ \\
\hline $\mathrm{XC10}$ & 49 & 59 & 128 & 115 \\
$\mathrm{XC38}$ & 65 & 94 & 176 & 141 \\
$\mathrm{XC100}$ & 72 & 109 & 198 & 159 \\
\hline
\end{tabular}

Table 3 : Yield stress and maximal stress $\left(800^{\circ} \mathrm{C}\right)$. 
* $\mathrm{A}_{\mathrm{m}}<\mathrm{T}^{\circ}$ nom $=1100^{\circ} \mathrm{C}$

Since the austenitization process is completed $[9,12]$, the evolution of the true stress is independent on the carbon concentration at the heating rate of $10^{\circ} \mathrm{C} / \mathrm{s}$ as shown in figure 7 .

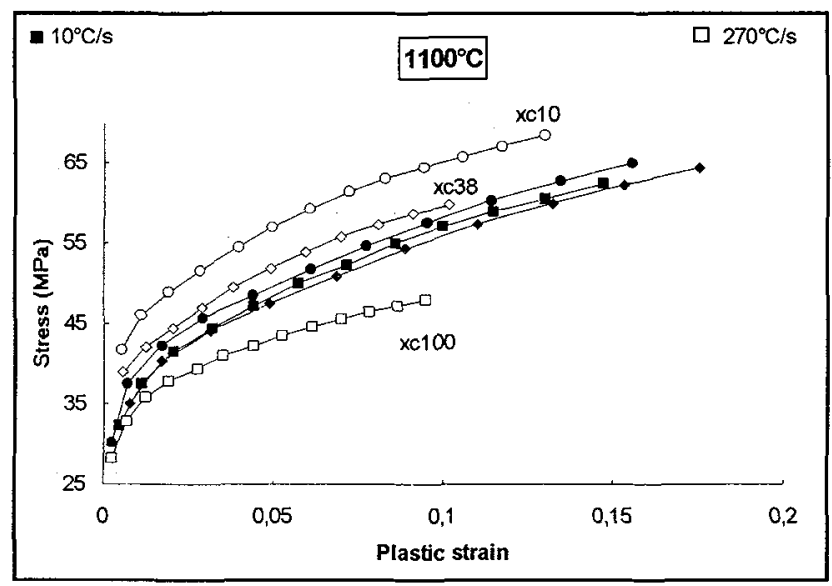

Figure 7 : True plastic stress vs plastic strain $\left(1100^{\circ} \mathrm{C}\right)$.

\begin{tabular}{ccccc} 
& \multicolumn{2}{c}{$\sigma_{02} \%(\mathrm{MPa})$} & \multicolumn{2}{c}{$\sigma_{\mathrm{m}}(\mathrm{MPa})$} \\
\cline { 2 - 5 } & $10^{\circ} \mathrm{C} / \mathrm{s}$ & $270^{\circ} \mathrm{C} / \mathrm{s}$ & $10^{\circ} \mathrm{C} / \mathrm{s}$ & $270^{\circ} \mathrm{C} / \mathrm{s}$ \\
\hline $\mathrm{XC10}$ & 23 & 32 & 65 & 68 \\
$\mathrm{XC38}$ & 21 & 28 & 64 & 59 \\
XC100 & 25 & 27 & 62 & 48 \\
\hline
\end{tabular}

Table 4 : Yield stress and maximal stress $\left(1100^{\circ} \mathrm{C}\right)$.

Except for the $1 \% \mathrm{C}$ steel, yield stress and flow stress increase with the rate of heating. As earlier observed in the literature [15], the austenite grain size is a decreasing function of the heating rate. This is the major factor which explains the strengthening of the materials in this range of temperature.

\subsection{Strain hardening and viscosity parameters}

As deduced from (1), the strain hardening factor and the strain rate sensitivity parameter can be respectively determined from tensile and relaxation tests, using the following relationships :

$$
\begin{aligned}
& \mathrm{n}=\left(\frac{\partial \ln \sigma}{\partial \ln \varepsilon \mathrm{p}}\right)_{\mathrm{T}^{\circ}, \dot{\varepsilon}} \\
& \mathrm{m}=\left(\frac{\partial \ln \sigma}{\partial \ln \dot{\varepsilon} \mathrm{p}}\right)_{\mathrm{T}^{\circ}, \varepsilon}
\end{aligned}
$$

The results issued from our tests are given in figures $8->13$. 
Concerning the strain hardening factor, no major influence of the heating rate has been pointed out within the range of temperature of $600^{\circ} \mathrm{C}$ (fig.8).

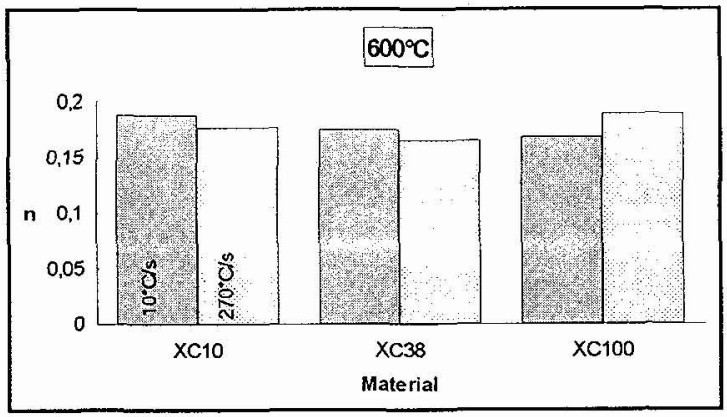

Figure 8 : Strain hardening factor at $600^{\circ} \mathrm{C}$.

For the other temperatures levels, and for each material, the strain hardening factor decreases with the rate of heating. As above-mentioned, at $800^{\circ} \mathrm{C}$ (fig.9), this may be the consequence of the incomplete dissolution of carbides. Indeed, when considering the higher rate of heating, the recrystallisation is more advanced since new dislocations are generated by these cementite particles [16]

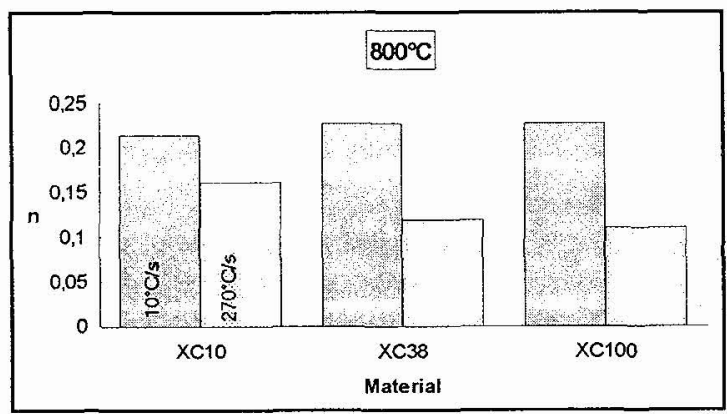

Figure 9: Strain hardening factor at $800^{\circ} \mathrm{C}$.

Above $A_{m}$ (fig. 10), the recrystallization, function of the austenitic grain size which is itself controlled by the heating rate, added to the homogeneity of the austenite are the prevailing factors which explains the evolution of " $n$ ".

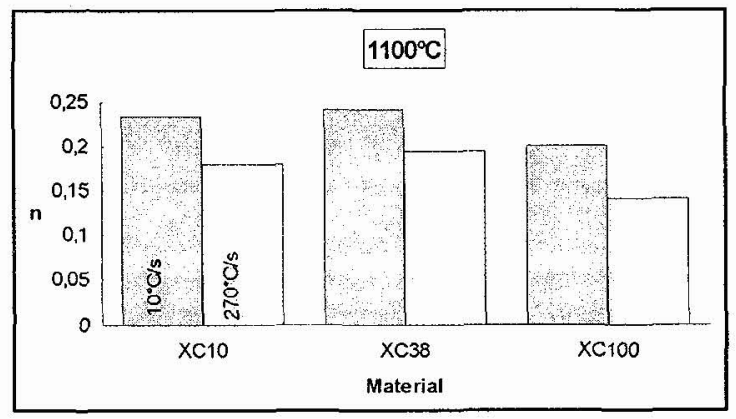

Figure 10 : Strain hardening factor at $1100^{\circ} \mathrm{C}$. 
Concerning the strain rate sensitivity exponent $\mathrm{m}$, as expected this parameter is highly temperature dependent. For each material and each heating rate, $\mathrm{m}$ is an increasing function of the temperature.

In other respects, when considering results for the lower temperature $\left(\mathrm{T}^{\circ}=600^{\circ} \mathrm{C}\right) \mathrm{m}$ does not seem to be heating rate dependent (fig.11).

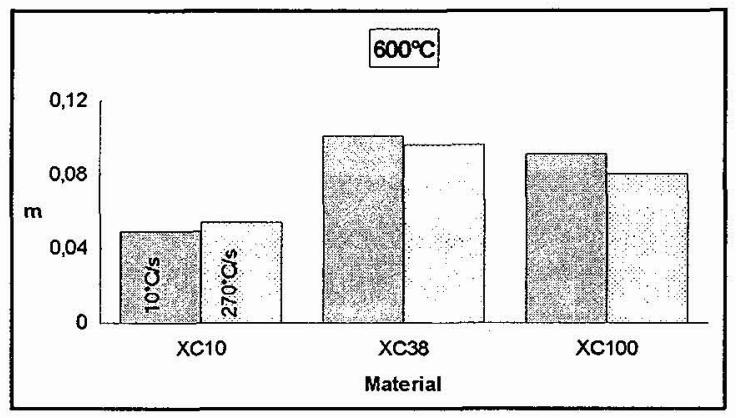

Figure 11 : Strain rate sensitivity exponent at $600^{\circ} \mathrm{C}$.

Above $\mathrm{A}_{1}\left(\mathrm{~T}^{\circ}=800^{\circ} \mathrm{C}\right)$, the higher values obtained for the higher heating rate may be probably the consequence of the recrystallisation process (fig. 12).

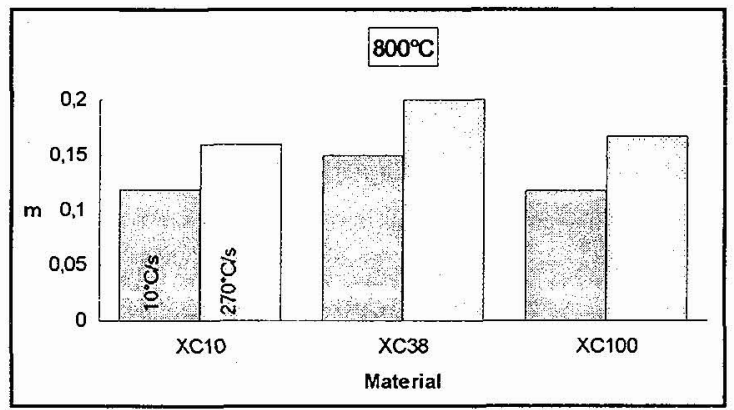

Figure 12 : Strain rate sensitivity exponent at $800^{\circ} \mathrm{C}$.

Above $A_{m}$ (fig. 13), the heating rate effects on $m$ are inversed. But for this range of temperature, because of the low level of loading, stress relaxation measurements are extremely difficult to implement and consequently these results certainly suffer of a lack of accuracy.

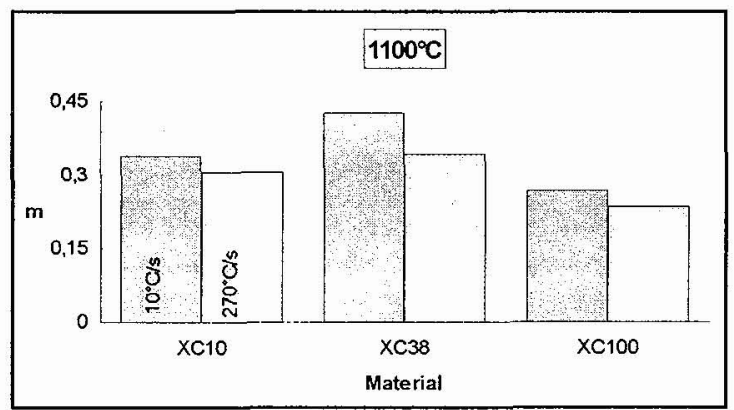

Figure 13 : Strain rate sensitivity exponent at $1100^{\circ} \mathrm{C}$. 


\section{CONCLUSION :}

In this work, the dependence of mechanical behaviour of carbon steels on heating rate has been pointed out.

This parameter clearly affects the mechanical properties such as yield and flow stresses as well as the strain hardening factor and the strain rate sensitivity exponent.

At $600^{\circ} \mathrm{C}$, a essential decrease of the yield and flows stresses, which is of a great interest in an industrial point of view, has been pointed out for the higher value of the heating rate.

Above A1, some modifications of mechanical properties are attributed to homogeneity of austenite and its grain size because they are sensitive to the heating rate.

Other mechanisms, such as the dislocation motion or the dissolution of carbides, need complementary observations since their respective influence on the mechanical properties has been introduced in an intuitive manner.

Nevertheless, since only two extreme values of this parameter have been investigated, it would be necessary to get more results for intermediate values in order to understand how this parameter acts on the above mentioned processes.

\section{References}

[1] Brunner D. and Diehl J., Phys. Stat. Sol. (a), Vol 124, (1991), pp.455-464.

[2] Haque M.M., Hashmi M.S.J. and Pickering F.B., Mater. Forum, Vol 10, n³, (1987), pp. 214-217.

[3] Pierson G., Metauer G. and Gantois M., Rev. Metall. : M.E.S., Vol 81, n5, (1984), pp. 239-247.

[4] Rossard C. and Fazan B., Comportement mécanique et métallurgique des aciers et de certains métaux en cours de déformation à chaud, Cahiers du Cessid, (ed Berger \& Levrault, Metz, 1968), pp.9-32.

[5] Porter D.A. and Easterling K.E., Phase transformation in metals and alloys, (ed Chapman \& Hall, London, 1981), pp.172-175.

[6] Räsänen E. and Tenkula J., Scand. J. Metall., n¹, (1972), pp.75-80.

[7] Albut K.J. and Garber S., J. Iron Steel Inst., (1966), pp.1217-1222.

[8] Nikishov N.A., Sokolov A.M. and Ul'yanov V.G., Met. Sci. Heat Treat., Vol 33, n7-8, (1991), pp. 561-564.

[9] Orlich J., Trait. Therm., n90, (1974), pp.69-75.

[10] Farias D., Denis S. and Simon A., Trait. Therm., n²37, (1990), pp.63-70.

[11] Lemaitre J. and Chaboche J.L., Mécanique des matériaux solides, (ed Dunod, Paris, 1988).

[12] Schlicht H., Trait. Therm., n89, (1974), pp.63-77.

[13] Sainfort G., Le rôle des joints dans les métaux, Ecole d'été de Métallurgie physique, (Carry-le-Rouet, 1984).

[14] Gridnev V.N., Meshkov Yu.Ya., Oshkaderov S.P. and Schernenko N.F., Les bases technologiques des traitements électro-thermique des aciers (russe), (ed Naukova Dumka, Kiev, 1977), pp.41-48.

[15] Orlich J., Rose A., Wiest P. and Pietrzeniuk H.J., Atlas zür wärmebehandlung der stähle, (Berlin, 1976).

[16] Wagenblast H. and Glenn R.C., Metall. Trans., Vol 1, (1970), pp.2299-2304. 